\title{
Pengaturan Pembangkit Listrik Tenaga Uap Batubara Di Indonesia Prespektif Hak Atas Lingkungan Yang Baik Dan Sehat
}

\author{
Theo Alif Wahyu Sabubu \\ Magister Ilmu Hukum Universitas Islam Indonesia Yogyakarta \\ Jln. Cik Di Tiro No. 1, Yogyakarta, 55223 \\ theosabubu@gmail.com
}

\begin{abstract}
The main problem in this writing is, first, how is the right to a decent and healthy environment in the governance of coal Steam Power Plant (PLTU)?; second, how is the future governance concept? The analysis used is descriptive-qualitative method. There are two approaches to be used in this research, namely the legal approach and the case approach. The results of this study conclude that all the regulations that form the basis of coal PLTU have not provided protection and fulfillment of the right to a decent and healthy environment. The concept of future regulation can be seen from three aspects, namely legal substance, legal culture, and law enforcement. From the aspect of its legal substance, it can be seen that there is no clear and firm regulation regarding coal PLTU, it also requires an instrument on the location and the Clean Air Act. For the legal culture, it is more focused on sustainable and environmentally friendly development. As for the law enforcement, there are still some regulations that are not implemented by the company concerned, for example in coal mining.
\end{abstract}

Key Words: Power plant; right to environment; decent and healthy

\begin{abstract}
Abstrak
Pokok permasalahan dalam tulisan ini yaitu, pertama bagaimana hak atas lingkungan yang baik dan sehat dalam pengaturan Pembangkit Listrik Tenaga Uap (PLTU) batubara?; kedua, bagaimana konsep pengaturan kedepannya? Analisis yang akan digunakan adalah analisis deskriptif-kualitatif. Ada dua pendekatan yang akan dilakukan dalam penelitian ini yaitu pendekatan undang-undang dan pendekatan kasus. Hasil penelitian ini menyimpulkan bahwa semua pengaturan yang menjadi landasan mengenai PLTU Batubara belum memberikan perlindungan dan pemenuhan terhadap hak atas lingkungan hidup yang baik dan sehat. Konsep pengaturan kedepannya dilihat dari tiga aspek yaitu substansi hukum, budaya hukum, serta penegakan hukum. Dari aspek substansi hukumnya dapat dilihat bahwa tidak ada pengaturan yang jelas dan tegas mengenai PLTU Batubara, dibutuhkan juga instrumen mengenai lokasi dan Clean Air Act. Untuk budaya hukumnya, lebih difokuskan pada pembangunan yang berkelanjutan dan berwawasan lingkungan. Serta penegakan hukumnya, masih ada beberapa aturan yang tidak dijalankan oleh perusahaan yang bersangkutan misalnya dalam penambangan batubara.
\end{abstract}

Kata-kata Kunci: Pembangkit listrik; hak atas lingkungan; baik dan sehat 


\section{Pendahuluan}

Kesehatan merupakan hak asasi manusia dan salah satu unsur kesejahteraan yang harus diwujudkan sesuai dengan cita-cita bangsa Indonesia sebagaimana dimaksud dalam Pancasila dan Pembukaan Undang-Undang Dasar Negara Republik Indonesia Tahun 1945 (UUD NRI 1945). ${ }^{1}$ Hak Asasi Manusia (HAM) merupakan hak yang melekat pada setiap orang sejak ia lahir sampai meninggal dunia. UUD NRI 1945, mengamanatkan mengenai hak asasi manusia terhadap kesehatan yang diejawantahkan dalam batang tubuh yang menyatakan, "Setiap orang berhak hidup sejahtera lahir dan batin, bertempat tinggal, dan mendapatkan lingkungan hidup yang baik dan sehat serta berhak memperoleh pelayanan kesehatan". ${ }^{2}$ Bukan hanya hak atas kesejahteraan hidup lahir maupun batin, orang juga berhak untuk mendapatkan lingkungan yang baik pula.

Ketentuan lebih lanjut yang disebutkan dalam UU Nomor 32 Tahun 2009 tentang Perlindungan dan Pengelolaan Lingkungan Hidup Pasal 65 ayat (1) nya menyebutkan bahwa "Setiap orang berhak atas lingkungan hidup yang baik dan sehat sebagai bagian dari hak asasi manusia". Ketentuan dalam pasal ini memberikan kejelasan bahwa komponen lingkungan hidup merupakan hak asasi manusia yang menunjang hak hidup dari manusia itu sendiri. Sebagai bagian dari hak hidup manusia, maka hak atas lingkungan hidup yang baik dan sehat itu menjadi tidak dapat diganggu gugat ataupun menguranginya dalam kondisi apapun.

Sebagai salah satu pembangkit listrik yang ada di tanah air Indonesia, Pembangkit Listrik Tenaga Uap (PLTU) Batubara merupakan tumpuan pemerintah dalam penyediaan listrik tanah air. Tidak hanya murah, bahan baku PLTU sendiri yaitu batu bara cukup mudah untuk di dapatkan karena tambang batu bara itu sendiri cukup banyak di Indonesia. Di Indonesia sudah ada hampir 100 PLTU Batubara yang tersebar di seluruh tanah air, yang sebagian besar tersebar di pulau Jawa, dan pembangunan PLTU ini akan berlanjut dengan ditambahnya 35 PLTU lagi yang 10 buah PLTU nya dibangun di pulau jawa dan 25 sisanya dibangun di luar pulau jawa. ${ }^{3}$ Keberadaan PLTU ini bukan hanya memberikan kita listrik yang bisa digunakan tiap harinya, tetapi juga memberikan pekerjaan/menyerap tenaga kerja bagi masyarakat yang tinggal di sekitar PLTU yang artinya tingkat pendapatan masyarakat sekitar PLTU itu bisa

\footnotetext{
hlm. 46.

1 Titon Slamet Kurnia, Derajat Kesehatan Optimal sebagai HAM di Indonesia, PT Alumni, Bandung, 2007,

2 Pasal 28H ayat (1) Undang-Undang Dasar Negara Republik Indonesia Tahun 1945 (UUD NRI 1945).

3 https://id.wikipedia.org/wiki/Daftar pembangkit listrik di Indonesia "Daftar Pembangkit Listrik di Indonesia” Akses tanggal 12 Agustus 2019
} 
meningkat. Tetapi tanpa kita sadari bahwa PLTU yang menghasilkan panas listrik pada siklus pembakarannya, ternyata menghasilkan polutan lain juga yang ternyata cukup berbahaya bagi kesehatan maupun lingkungan. Polutan yang dihasilkan berupa SOx, NOx, CO dan partikel yang berupa fly ash yang dikeluarkan melalui cerobong asap yang kemudian bisa dihembuskan oleh angin dan membawa debu ke masyarakat sekitar yang tinggal di dekat PLTU tersebut.

Polusi udara merupakan pembunuh senyap, yang mengakibatkan lebih dari 3 juta jiwa meninggal dunia. Di 2016 polusi udara telah menyebabkan lebih dari 4 juta jiwa meninggal. Laporan terbaru dari World Health Organization (WHO) tahun 2018 mengatakan bahwa 7 juta orang tewas tiap tahun karena polusi udara ${ }^{4}$. Di Indonesia sendiri menurut hasil penelitian yang dilakukan oleh tim peneliti Harvard University-Atmospheric Chemistry Modeling Group menyatakan bahwa kematian dini yang diakibatkan oleh polusi udara dari operasi PLTU Batubara telah menyebabkan sekitar 6.500 jiwa pertahun, dan akan meningkat menjadi 15.700 jiwa/tahun, jika pembangunan PLTU Batubara terus berlanjut. Lebih lanjut pada tahun 2008 Indonesia menyumbang pembakaran batubara menyumbang sekitar 50\% dari emisi $\mathrm{SO}_{2}$ yang terkait sektor energi, 30\% dari emisi PM10 dan $28 \%$ dari emisi NOx 5 . PLTU dapat menyebabkan asma, infeksi pernafasan akut dan sebagainya. Resiko penyakit ini meningkat bagi orang yang tinggal disekitaran PLTU. Hasil pembakaran PLTU ini yang berupa partikel-partikel halus itu selain debu yang dapat kita lihat kalau jumlahnya sudah banyak, dapat masuk menembus hingga paru-paru dan juga aliran darah yang dapat menyebabkan kematian dan juga masalah kesehatan lainnya. Bukan hanya pada masalah kesehatan masyarakatnya yang ditimbulkan, tetapi juga masalah pencemaran lingkungan. Pencemaran yang dilakukan akibat polutan dari PLTU ini bisa mempengaruhi ekosistem air laut, kekurangan ruang terbuka hijau, cuaca yang semakin memanas, dan juga polusi yang semakin membanyak. Tidak hanya sampai disitu, masyarakat yang mendapatkan dampak dari PLTU ini terutama yang tinggal di sekitar PLTU harus mengeluarkan biaya yang lebih jika sakit karena penyakit yang ditimbulkan bukan merupakan sakit yang biasa seperti demam atau semisalnya, tetapi bisa menyebabkan resiko kanker paru-paru meningkat, stroke, dan juga penyakit jantung. Disisi lain kerentanan terhadap anak kecil, bayi, ibu hamil dan orang tua/lansia juga meningkat karena efek akut dari polusi udara ini.

\footnotetext{
https://news.detik.com/dw/d-4001541/who-7-juta-orang-tewas-tiap-tahun-karena-polusi-udara "WHO: 7 Juta Orang Tewas Tiap Tahun Karena Polusi Udara” Akses 8 Agustus 2019

5 Greenpeace, "Internalisasi Dampak dan Biaya Kesehatan dari Pembangkit Listrik Tenaga Uap (PLTU) Batubara di Indonesia", Laporan, September 2016, hlm. 4
} 
Perubahan iklim global yang terjadi diakibatkan karena penggunaan yang berlebihan dari bahan bakar fosil seperti batu bara, produk minyak bumi, gas alam yang dihasilkan dari pembangkit tenaga listrik, transportasi, pabrik dan sebagainya telah memberikan miliaran ton karbon yang dilepaskan ke atmosfer6. Di beberapa tempat ada PLTU yang berada tidak jauh dari pemukiman warga, ini dapat memberikan dampak negatif yang didapatkan oleh warga sekitar, terutama masalah kesehatan. Padahal dalam UU Kesehatan pemerintah menjamin ketersediaan lingkungan yang sehat dan tidak mempunyai resiko buruk bagi kesehatan. Dalam UU Nomor 36 Tahun 2009 tentang Kesehatan tersebut selain jaminan pemerintah mengenai lingkungan yang sehat dan tidak mempunyai risiko buruk bagi kesehatan, dalam upaya mewujudkan kualitas lingkungan yang sehat tersebut ditujukan untuk mencapai derajat kesehatan yang setinggi-tingginya. Lingkungan yang sehat tentu lingkungan yang terbebas dari timbulnya gangguan kesehatan, dalam undangundang ini salah satu contoh lingkungan yang sehat adalah terbebas dari air dan udara yang tercemar maupun limbah baik itu berupa cair, padat, dan gas. Pencemaran udara maupun air di sekitar kawasan PLTU tentu memberikan dampak negatif yang mengganggu kesehatan bagi masyarakat sekitar.

\section{Rumusan Masalah}

Berdasarkan pendahuluan di atas ada beberapa pokok permasalahan yang ingin penulis bahas, pertama bagaimana hak atas lingkungan yang baik dan sehat dalam pengaturan PLTU Batubara? Kedua, bagaimana konsep pengaturan kedepannya?

\section{Tujuan Penelitian}

Penelitian ini memiliki tujuan: pertama, menganalisis pengaturan PLTU Batu Bara di Indonesia menggunakan perspektif HAM yang fokusnya pada hak atas lingkungan yang baik dan sehat. Kedua, memberikan masukan tentang konsep pengaturan yang lebih baik kedepannya demi terwujudnya hak atas lingkungan yang baik dan sehat bagi seluruh masyarakat.

\section{Metode Penelitian}

Ada dua pendekatan yang akan dilakukan dalam penelitian ini: pertama, yaitu pendekatan undang-undang (Statute Approach) dimana undang-undang

${ }^{6}$ I Made Astra, "Energi dan Dampaknya Terhadap Lingkungan", Jurnal Meteorologi dan Geofisika, Vol. 11 No. 2, November 2010, hlm. 137 
sebagai bahan hukum digunakan untuk menganalisis kebijakan pemerintah dalam pembangunan pembangkit listrik tenaga uap batubara; kedua, pendekatan kasus (Case Approach) yaitu untuk mendukung argumentasi dari pendekatan pertama tadi dengan menyajikan kasus-kasus mengenai PLTU Batubara di Indonesia. Karena penelitian ini menggunakan pendekatan undang-undang juga, maka dapat dikategorikan sebagai penelitian normatif. Bahan hukum dalam penelitian ini ada dua yaitu: bahan hukum primer dan bahan hukum sekunder. Analisis yang akan digunakan adalah analisis deskriptif-kualitatif.

\section{Hasil Penelitian dan Pembahasan}

\section{Hak Atas Lingkungan yang Baik dan Sehat}

Kesehatan lingkungan merupakan penunjang untuk mencapai derajat kesehatan yang setinggi-tingginya. Maka dari itu hak atas kesehatan lingkungan tidak dapat dipisahkan dengan hak atas kesehatan juga. Pasal 12 ayat (1) Kovenan Hak Ekonomi Sosial dan Budaya (EKOSOB) yang telah disebutkan sebelumnya, pasal tersebut juga mengacu kepada "kesehatan lingkungan hidup", karena standar tertinggi untuk kesehatan jasmani tidak hanya diperoleh dari terpenuhinya gizi untuk badan tetapi juga lingkungan yang baik dan sehat. Bahkan didalam ayat (2) nya huruf b dengan tegas menyatakan "perbaikan seluruh aspek kesehatan lingkungan dan industri". Redaksi yang digunakan pada Pasal 12 ayat (2) huruf b ini, nampaknya menunjukkan bahwa adanya suatu kewajiban untuk menahan diri dari tindakan tertentu. Tindakan tersebut juga menunjukkan bahwa ada suatu kewajiban pada negara yang membuat dan telah meratifikasi kovenan tersebut untuk memperbaiki kondisi kehidupan penduduknya melalui langkah-langkah khusus yang menyangkut lingkungan hidup manusia.

Hak atas lingkungan yang baik dan sehat sangat terkait dengan pencapaian kualitas hidup manusia, sehingga hak atas lingkungan hidup yang baik dan sehat tidak dapat dikurangi dalam kondisi apapun. Di samping itu, tidak diperbolehkan adanya jenis-jenis diskriminasi apapun dalam penghormatan hak atas lingkungan hidup. Nilai universal hak asasi manusia yang kemudian diterjemahkan dalam berbagai produk hukum nasional di berbagai negara untuk dapat melindungi dan menegakkan nilai-nilai kemanusiaan. Bahkan nilai universal ini dikukuhkan dalam instrumen internasional, termasuk perjanjian internasional di bidang HAM. ${ }^{7}$

${ }^{7}$ Masrudi Muchtar et.al., Hukum Kesehatan Lingkungan (Kajian Teoritis dan Perkembangan Pemikiran), Pustaka Baru Press, Yogyakarta, 2017, hlm. 37 
Jaminan terhadap kesehatan dan hak atas kesehatan lingkungan telah tertuang pada batang tubuh UUD 1945 Amandemen ke IV, pada Pasal 28H ayat (1) menyebutkan bahwa

"Setiap orang berhak hidup sejahtera lahir dan batin, bertempat tinggal, dan mendapatkan lingkungan hidup yang baik dan sehat serta berhak memperoleh pelayanan kesehatan".

Pasal tersebut memberikan mandat kepada negara untuk bertanggung jawab dan berkewajiban dalam pemenuhan hak atas pelayanan kesehatan yang baik bagi seluruh warga negara dalam rangka mewujudkan masyarakat Indonesia yang hidup sehat sejahtera lahir dan batin. Dengan demikian pula, Pasal $28 \mathrm{H}$ ayat (1) ini memberikan kewajiban kepada pemerintah untuk menyediakan layanan kesehatan bagi rakyat/warga negaranya yang membutuhkan. Sementara hak atas perlindungan kesehatan mewajibkan negara/pemerintah melakukan pengaturan-pengaturan supaya kesehatan setiap orang selaku pemegang hak (right holder) aman dari masalah-masalah yang mengancam kesehatan tersebut. ${ }^{8}$

Pasal tersebut tidak hanya tentang kesejahteraan hidup lahir maupun batin, juga terdapat hak untuk mendapatkan lingkungan hidup yang baik dan sehat. Artinya bahwa secara yuridis kedua hak tersebut telah dijamin oleh UUD 1945 kita. Pasal 9 ayat (1) Undang-Undang Nomor 29 Tahun 1999 tentang HAM menyebut bahwa "Setiap orang berhak untuk hidup, mempertahankan hidup dan meningkatkan taraf kehidupannya." Mempertahankan dan meningkatkan taraf kehidupannya memberikan makna bahwa terdapat jaminan untuk tiap-tiap individu untuk memiliki kebebasan berusaha demi peningkatan kualitas kehidupannya. Hidup dan kehidupan ayat (1) ini kemudian memberikan pengertian lebih lanjut di ayat (2) nya, bahwa "Setiap orang berhak tenteram, aman, damai, bahagia, sejahtera lahir dan batin." Dalam peningkatan kualitas kehidupan seseorang merujuk bukan hanya pada kesehatan jasmani saja, akan tetapi merujuk pula pada kesehatan lingkungannya untuk memperoleh lingkungan yang bersih dan sehat sebagaimana disebutkan pada ayat (3) nya yaitu "Setiap orang berhak atas lingkungan hidup yang baik dan sehat". Pasal 6 Undang-Undang Nomor 36 Tahun 2009 tentang kesehatan menyatakan "Setiap orang berhak mendapatkan lingkungan yang sehat bagi pencapaian derajat kesehatan". Bahkan dalam undang-undang ini juga menyatakan bahwa upaya kesehatan lingkungan

8 Yahya Ahmad Zein, Hak Warga Negara Di Wilayah Perbatasan (Perlindungan Hukum Hak Atas Pendidikan dan Kesehatan), Liberty, Yogyakarta, 2016, hlm. 218-219. 
memiliki tujuan yaitu derajat kesehatan yang setinggi-tingginya. Pasal 162 undang-undang ini

"Upaya kesehatan lingkungan ditujukan untuk mewujudkan kualitas lingkungan yang sehat, baik fisik, kimia, biologi, maupun sosial yang memungkinkan setiap orang mencapai derajat kesehatan yang setinggi-tingginya".

Jaminan atas ketersediaan lingkungan yang sehat dan tidak mempunyai risiko yang buruk bagi kesehatan merupakan tugas dari pemerintah, pemerintah daerah maupun masyarakat ${ }^{9}$. Ada sebelas indikator yang mana dapat dikatakan lingkungan yang sehat itu terbebas dari unsur yang menimbulkan gangguan kesehatan yaitu "limbah cair, limbah padat, limbah gas, sampah yang tidak diproses sesuai dengan persyaratan yang ditetapkan pemerintah, binatang pembawa penyakit, zat kimia berbahaya, kebisingan yang melebihi ambang batas, radiasi sinar pengion dan non pengion, air yang tercemar, udara yang tercemar dan makanan yang terkontaminasi"10.

Dalam Undang-Undang Nomor 32 Tahun 2009 tentang Perlindungan dan Pengelolaan Lingkungan Hidup (PPLH), ada beberapa hak yang diakui oleh undang-undang ini, yaitu: "(1) hak atas lingkungan hidup yang baik dan sehat yang merupakan bagian dari hak asasi manusia, (2) hak untuk mendapatkan pendidikan lingkungan hidup, (3) hak atas akses informasi, (4) hak untuk berpartisipasi, (5) hak untuk mengajukan usul dan/atau keberatan terhadap rencana usaha dan/atau kegiatan yang diperkirakan dapat memberikan dampak terhadap lingkungan, (6) hak untuk perannya dalam perlindungan dan pengelolaan lingkungan hidup, (7) hak untuk mengadu akibat dugaan pencemaran dan/atau perusakan lingkungan hidup, (8) hak untuk tidak dituntut secara pidana maupun digugat secara perdata"11. Semua hak tersebut tentu dalam rangka memperjuangkan hak atas lingkungan hidup yang baik dan sehat.

Salah satu tujuan dari perlindunan dan pengelolaan lingkungan hidup adalah menjamin pemenuhan dan perlindungan hak atas lingkungan hidup sebagai bagian dari hak asasi manusia ${ }^{12}$ yang berarti konsep ini mengakomodir dua hak sekaligus yaitu hak lingkungan atas kualitas lingkngan hidup yang baik dan hak manusia untuk menikmati lingkungan idup tersebut sehingga kehidupan dapat berjalan dengan harmonis.

Pasal 5 ayat (1) UU No. 23 Tahun 1997 menyebutkan bahwa "Setiap orang mempunyai hak yang sama atas lingkungan hidup yang baik dan sehat". Undang-

${ }_{9}^{9}$ Lihat, Pasal 163 ayat (1) Undang-Undang Nomor 32 Tahun 2009 tentang Perlindungan dan Pengelolaan Lingkungan Hidup (UU 32/2009)

${ }^{10}$ Pasal 163 ayat (3) UU 32/2009

11 Lihat Pasal 65 dan 66 UU 32/2009

12 Lihat Pasal 3 Huruf g UU 32/2009 
Undang No. 32 Tahun 2009 menempatkan hak atas lingkungan yang baik dan sehat ini pada landasan filosofisnya. Sehingga hak atas lingkungan yang baik dan sehat ini mendapatkan tempat yang paling tinggi, juga merupakan sebagai hak asasi bagi setiap warga yang dijamin oleh negara. Untuk mewujudkan hak atas lingkungan hidup yang baik dan sehat dibutuhkan peran pemerintah, pemerintah daerah maupun masyarakat. Ketiga perangkat ini memiliki peran dan fungsinya masing-masing, juga harus menjalin kerjasama yang baik untuk melindungi dan mengelola lingkungan hidup.

Perlindungan dan pengelolaan lingkungan hidup adalah upaya terpadu untuk melestarikan fungsi lingkungan hidup yang meliputi kebijaksanaan penataan, pemanfaatan, pengembangan, pemeliharaan, pemulihan, pengawasan, dan pengendalian lingkungan hidup. Perlindungan dan pengelolaan lingkungan hidup dapat meningkatkan kualitas dari lingkungan hidup yang baik dan sehat. Untuk meningkatkan lingkungan hidup yang baik dan sehat dapat dilakukan dengan cara sosialisasi, penyuluhan, pelatihan, pendidikan lingkungan hidup di sekolah, kantor-kantor pemerintahan maupun dilingkungan tempat tinggal, pengkajian dan penelitian tentang lingkungan, seminar dan diskusi, serta memanfaatkan media sebagai sarana pengetahuan bagi masyarakat untuk berpartisipasi dalam perlindungan dan pengelolaan lingkungan hidup. ${ }^{13}$

Ada keterkaitan antara perlindungan hak asasi manusia terhadap lingkungan hidup. Lingkungan hidup merupakan bagian yang mutlak dari kehidupan manusia. Dengan kata lain lingkungan hidup tidak terlepas dari kehidupan manusia. Lingkungan yang rusak menjadikan hak atas lingkungan yang baik dan sehat pada masyarakat terganggu. Sehingga perusakan lingkungan dapat juga dikatakan sebagai "pelanggaran HAM". Maka dari itu UndangUndang Nomor 32 Tahun 2009 merupakan payung hukum dan jaminan atas Hak Atas Lingkungan yang Baik dan Sehat. Pengaturan mengenai hak atas lingkungan yang baik dan sehat ini yang merupakan bagian dari hak asasi manusia yang dimuat dalam konstitusi kita, seakan memberitahukan bahwa pentingnya regulasi tersebut. Hak yang fundamental seperti ini tentu melekat kepada tiap manusia untuk pembangunan kehidupan manusia yang lebih baik.

${ }^{13}$ Rika Erawaty dan Siti Kotijah, "Hak Masyarakat Atas Lingkungan Hidup yang Baik dan Sehat" Risalah Hukum, Vol. 9 No. 1 Juni 2013, hlm. 93. 


\section{Hak Atas Lingkungan Hidup yang Baik dan Sehat dalam Pengaturan PLTU Batubara di Indonesia}

Asas dan tujuan yang dianut oleh Undang-Undang Nomor 30 Tahun 2007 tentang Energi ini salah satunya adalah terjaganya kelestarian fungsi lingkungan hidup yang dalam pengelolaannya energi harus memberikan jaminan terhadap kualitas maupun fungsi lingkungan yang lebih baik. Secara asas dan tujuan undang-undang ini telah memberikan jaminan untuk terpenuhinya hak atas lingkungan yang baik dan sehat, walaupun tidak secara eksplisit menyebutkan akan hal tersebut. Dalam Pasal 8 undang-undang ini mewajibkan dalam penggunaan teknologi yang ramah lingkungan dan memenuhi ketentuan yang disyaratkan dalam peraturan perundang-undangan di bidang lingkungan hidup. Begitu pula untuk pemanfaatan energi dilakukan berdasarkan asas dalam undang-undang ini yaitu, mengoptimalkan seluruh potensi sumber daya energi; mempertimbangkan aspek teknologi, sosial, ekonomi, konservasi, dan lingkungan; dan memprioritaskan pemenuhan kebutuhan masyarakat dan peningkatan kegiatan ekonomi di daerah penghasil sumber energi. Dalam pengusahaan energi pun badan usaha yang melakukan kegiatan usaha energi memiliki kewajiban salah satunya adalah menjaga dan memelihara fungsi kelestarian lingkungan.

PP No. 79 Tahun 2014 tentang Kebijakan Energi Nasional yang merupakan Induk dari Perpres No. 22 Tahun 2017 mengenai Rencana Umum Energi Nasional, memiliki dua garis besar kebijakan pengelolaan energi yaitu kebijakan utama dan pendukung. Kebijakan utama menurut peraturan ini meliputi ketersediaan energi untuk kebutuhan nasional; prioritas pengembangan energi; pemanfaatan sumber daya energi nasional; dan cadangan energi nasional. Sedangkan kebijakan pendukungnya yaitu konservasi energi, konservasi sumber daya energi, dan diverivikasi energi; lingkungan hidup dan keselamatan; harga, subsidi, dan insentif energi; infrastruktur dan akses untuk masyarakat terhadap energi dan industri energi; penelitian, pengembangan, dan penerapan teknologi energi; dan kelambagaan pendanaan. PP ini menjadi unik karena menurut saya ada sedikit pertentangan pada prinsip yang dianut oleh peraturan ini. Prinsip pertama mengharuskan kita untuk menggunakan energi terbarukan dalam pengembangan energi, tetapi pada prinsip ke empat malah menggunakan batubara sebagai andalan pasokan energi nasional. Jika kita melihat pada Undang-Undang No. 30/2007 tentang Energi, Pasal 1 Angka 6, "Sumber energi terbarukan adalah sumber energi yang dihasilkan dari sumber daya energi yang berkelanjutan jika dikelola dengan baik, antara lain panas bumi, angin, bioenergi, sinar matahari, aliran dan terjunan air, serta gerakan dan perbedaan suhu lapisan 
laut." Sedangkan angka 7 nya "Sumber energi tak terbarukan adalah sumber energi yang dihasilkan dari sumber daya energi yang aka habis jika dieksploitasi secara terus menerus, antara lain, minyak bumi, gas bumi, batu bara, gambut, dan serpih bitumen." Dari PP ini seakan-akan kita menginginkan penggunaan energi terbarukan, tetapi disisi lain kita tetap menggunakan energi tak terbarukan sebagai andalan. Padahal prinsip kebijakan energi nasional itu berkeadilan, berkelanjutan, dan berwawasan lingkungan. Selain itu juga dalam pengelolaan energi, pengendalian pencemaran lingkungan hidup pun diperhatikan. Kegiatan yang dilakukan guna penyediaan dan pemanfaatan energi diwajibkan untuk meminimalkan produksi limbah, penggunaan kembali limbah dalam proses produksi, penggunaan limbah untuk manfaat lain, juga diutamakan untuk menggunakan teknologi yang ramah lingkungan. Pun dalam Peraturan Presiden Nomor 1 Tahun 2014 tentang Pedoman Penyusunan Rencana Umum Energi Nasional, kebijakan mengenai pengelolaan energi itu berdasarkan prinsip berkeadilan, berkelanjutan, dan berwawasan lingkungan guna terciptanya kemandirian dan ketahanan energi nasional.

Undang-Undang Nomor 4 Tahun 2009 tentang Pertambangan Mineral dan Batubara. Ada 4 asas yang menjadi landasan untuk pertambangan minerba yaitu “1) manfaat, keadilan dan keseimbangan; 2) keberpihakan kepada kepentinga bangas; 3) partisipatif, transparansi, dan akuntabilitas; 4) berkelanjutan dan berwawasan lingkungan." Dalam pemanfaatan batubara pun undang-undang ini telah menjamin pemanfaatannya secara berkelanjutan dan berwawasan lingkungan hidup. Berkelanjutan dan berwawasan lingkungan disini adalah secara terencana mengintegrasikan dimensi ekonomi, lingkungan, dan sosial budaya dalam keseluruhan usaha pertambangan mineral dan batubara juga untuk mewujudkan kesejahteraan masa kini dan masa mendatanng. Indonesia sebenarnya hanya memiliki 3\% cadangan batubara dunia, tetapi eksplorasi batubara ini masih terus dilakukan.

Ada beberapa hal lain yang dituntut oleh undang-undang ini, agar kegiatan yang dilakukan memiliki nilai dan syarat lingkungan dalam menjalankan suatu proses yang tidak bisa diabaikan oleh tiap orang yaitu: pertama, dalam kewenangan yang dimiliki oleh pemerintah provinsi, pemerintah kabupaten/kota untuk mengembangkan dan meningkatkan peran serta masyarakat dalam usaha pertambangan yang mementingkan kelestarian lingkungan; kedua, yaitu pada wilayah pertambangan yang harus memperhatikan aspek ekologi serta berwawasan lingkungan, juga dalam pemberian wilayah izin usaha pertambangan dan wilayah pencadangan negara daya dukung lindungan 
lingkungan menjadi syarat untuk memperoleh izin; ketiga, dalam izin usaha pertambangan maupun izin usaha pertambangan khusus salah satu ketentuan didalamnya harus memuat mengenai lingkungan hidupnya begitu juga dengan persyaratan izin usaha pertambangan persyaratan lingkungan diwajibkan kepada badan usaha, koperasi atau perseorangan yang ingin melakukan usaha pertambangan, bukan hanya itu pemegang izin ini juga diwajibkan untuk melakukan pengelolaan serta pemantauan lingkungan pertambangan. Pemegang izin ini juga diwajibkan untuk menerapkan standar baku mutu lingkungan; keempat, dalam izin pertambangan rakyat yang memegang izin tersebut diwajibkan untuk mengelola lingkungan serta memenuhi standar yang berlaku yang dalam pengelolaannya dilakukan bersama pemerintah kabupaten/kota. Setiap kegiatan tersebut sebetulnya telah memberikan jaminan kepada masyarakat hak atas lingkungan yang baik dan sehat menurut undang-undang; kelima, dalam melakukan eksplorasi informasi mengenai lingkungan sosial dan lingkungan hidup dibutuhkan sebagai tahapan dalam kegiatan usaha pertambanagn, juga memberikan jaminan kesungguhan dalam biaya lingkungan yang diakibatkan oleh kegiatan eksplorasi ini serta mematuhi batas toleransi dan daya dukung lingkungannya; keenam, kegiatan reklamasi dan kegiatan pasca tambang yang dilakukan untuk menata kembali, memulihkan dan memperbaiki kualitas lingkungan serta ekosistem agar dapat menjalankan fungsi kembali sesuai dengan peruntukkanya. Pemulihan disini tidak hanya pemulihan fungsi lingkungan alam tetapi juga pemulihan fungsi sosial di seluruh wilayah pertambangan. Pengawasan yang dilakukan oleh aparat juga meliputi pengelolaan lingkungan hidup, reklamasi dan pasca tambang; ketujuh, apabila kondisi daya dukung lingkungan yang tidak dapat menanggung kegiatan usaha pertambangan lagi maka izin usaha pertambangan dan khusus dapat diberhentikan.

Undang-Undang Nomor 30 Tahun 2009 tentang Ketenagalistrikan. Salah satu asas dalam pembangunan ketenagalistrikan adalah kelestarian fungsi lingkungan. Asas kelestarian fungsi lingkungan ini dijelaskan lebih lanjut dalam penjelasan pasal demi pasalnya yaitu penyelenggaraan penyediaan tenaga listrik harus memperhatikan kelestarian fungsi lingkungan hidup dan lingkungan sekitar. Dalam usaha penyediaan tenaga listrik ini, undang-undang mengamanatkan untuk menggunakan energi baru dan energi terbarukan. UU 30/2007 memberikan penjelasan terhadap energi baru dan energi terbarukan. Disebutkan bahwa energi baru adalah energi yang dihasilkan oleh teknologi baru yang berasal dari energi terbarukan dan energi tak terbarukan antara lain nuklir, hidrogen, gas metana batu bara, batu bara tercairkan, dan batu bara tergaskan. Sedangkan untuk energi terbarukan dihasilkan dari sumber daya energi yang 
berkelanjutan jika dikelola dengan baik antara lain panas bumi, angin, bioenergi, sinar matahari, aliran dan terjunan air, serta gerakan dan perbedaan suhu lapisan laut. Dalam UU 30/2009 ini juga memberikan ketentuan bahwa setiap kegiatan usaha ketenagalistrikan wajib memenuhi ketentuan yang disyaratkan dalam peraturan perundang-undangan dibidang lingkungan hidup. Dalam tujuan usaha ketenagalistrikan memiliki tujuan untuk mewujudkan kondisi andal dan aman bagi instalasi, aman dari bahaya bagi manusia dan makhluk hidup lainnya, juga tentu yang ramah lingkungan. PLTU Batubara merupakan salah satu pembangkit listrik dalam memenuhi kebutuhan listrik nasional. Dalam rencana pembangunan 35000MW masih didominasi oleh PLTU Batubara ini.

Dalam undang-undang 30/2009 tentang Ketenagalistrikan pemerintah dan pemerintah daerah memiliki kewenangan untuk menetapkan kebijakan, pengaturan, pengawasan, dan melaksanakan usaha penyediaan tenaga listrik. Pasal 5 ayat (1) huruf $\mathrm{f}$ undang-undang memberikan kewenangan kepada pemerintah untuk menetapkan wilayah usaha, izin usaha maupun izin operasi juga, pemerintah provinsi maupun pemerintah kabupaten/kota memiliki kewenangan untuk penetapan izin usaha dan izin operasi. Melihat PLTU Batubara merupakan pembangkit listrik yang dalam artian lain merupakan pengusahaan atau penyediaan tenaga listrik, maka berdasarkan undang-undang ini dapat disimpulkan bahwa pengusahaan tenaga listrik merupakan tugas pemerintah dan pemerintah daerah yang berlandaskan prisnip otonomi daerah sehingga regulasi lebih lanjut mengenai lokasi untuk pembangunan PLTU Batubara berada ditangan pemerintah dan pemerintah daerah. Adapun regulasi yang menjadi landasan untuk pendirian PLTU Batubara dilokasi tertentu dikeluarkan oleh pemerintah daerah, karena dalam pembangunan PLTU Batubara melibatkan juga pemerintah daerah. Dalam usaha penyediaan tenaga listrik harus memenuhi izin lingkungan dan lokasinya dahulu. Nah izin lokasi ini yang dikeluarkan oleh pemerintah daerah setempat seperti pada PLTU Jawa-7 yang ada di Desa Terate, Kecamatan Kramatwatu Kabupaten Serang Provinsi Banten yang izin lokasinya dikeluarkan oleh Bupati Serang melalui Keputusan Bupati Serang Nomor 593/Kep.708-Huk.BPTPM/2015. Pada saat proses beroperasi PLTU di berbagai daerah menimbulkan kebisingan dan mengganggu kehidupan masyarakat meskipun dalam peraturan radius area PLTU dan pemukiman warga adalah sejauh $5 \mathrm{~km}$, akan tetapi asap yang ditimbulkan dari 
produksi batubara itu sendiri berbahaya karena mengikuti arah angin ${ }^{14}$. Rencana pembangunan tenaga listrik 35.000 MW yang diganyang oleh pemerintah dan PLN beberapa tahun silam, masih didominasi oleh PLTU Batubara. Ada 56,97\% dari total pembangkit listrik merupakan PLTU. ${ }^{15}$

Keseluruhan undang-undang diatas sebenarnya mengacu juga pada Undang-Undang Nomor 32 Tahun 2009 tentang Perlindungan dan Pengelolaan Lingkungan Hidup. Bahkan beberapa ketentuan didalam undang-undang sebelumnya diwajibkan sesuai dengan ketentuan undang-undang ini. Sebenarnya undang-undang ini telah memberikan jaminan perlindungan terhadap warganya, terutama hak atas lingkungan yang baik dan sehat. Tetapi yang menjadi permasalahan adalah dalam penerapannya. Masih ada saja oknum yang tidak bertanggungjawab melanggar ketentuan-ketentuan yang ada dalam undangundang ini maupun peraturan pelaksananya. Seperti yang kita tahu bahwa pasal 3 huruf g undang-undang ini berbunyi "perlindungan dan pengelolaan lingkungan hidup bertujuan: menjamin pemenuhan dan perlindungan hak atas lingkungan hidup sebagai bagian dari hak asasi manusia" juga disebutkan dalam pasal 65 undang-undang ini bahwa "setiap orang berhak atas lingkungan yang baik dan sehat sebagai bagia dari hak asasi manusia". Sehingga apabila kerusakan lingkungan terjadi maka hak atas lingkungan yang baik dan sehat ini dapat menimbulkan dampak negatif kepada masyarakat. Maka saya dapat mengatakan bahwa merusak lingkungan merupakan sebuah pelanggaran HAM juga dan juga pihak yang menjadi korban dapat melakukan penuntutan. Penuntutan ini dilindungi juga oleh undang-undang di pasal berikutnya pasal 66 "setiap orang yang memperjuangkan hak atas lingkungan hidup yang baik dan sehat tidak dapat dituntut secara pidana maupun digugat secara perdata". Ketentuan ini kita tau tentu untuk melindungi pelapor dari balasan terlapor melalui pidana atau perdata.

Sebelum kerusakan lingkungan terjadi, maka langkah yang harus diambil adalah melakukan pencegahan. Pasal 14 undang-undang ini memberikan instrumen pencegahan pencemaran dan/atau kerusakan lingkungan hidup yaitu : "kajian lingkungan hidup strategis, tata ruang, baku mutu lingkungan hidup, kriteria baku kerusakan lingkungan hidup, amdal, ukl-upl, perizinan, instrumen ekonomi lingkungan hidup, peraturan perundang-undangan berbasis lingkungan

14 Khoirullah Thofu "PLTU: ENERGI KOTOR YANG DIHASILKAN PRODUKSI LISTRIK BATUBARA (HULU DAN HILIR)” dalam https://www.lbhbali.or.id/berita/read/121/PLTU:-ENERGIKOTOR-YANG-DIHASILKAN-PRODUKSI-LISTRIK-BATUBARA--HULU-DAN-HILIR-.html akses tanggal 25 Februari 2020

15 "PLTU Mendominasi 56,97\% Program Listik 35.000 MW" dalam https://www.beritamoneter.com/ pltu-mendominasi-5697-program-listik-35-000-mw/ akses tanggal 25 Februari 2020 
hidup, anggaran berbasis lingkungan hidup, analisis risiko lingkungan hidup, audit lingkungan hidup dan instrumen lain sesuai dengan kebutuhan dan/atau perkembangan ilmu pengetahuan". Instrumen ini sebenarnya sudah cukup untuk mencegah terjadinya kerusakan dan pencemaran lingkungan hidup, akan tetapi dalam penerapannya masih belum efektif, sehingga masih banyak sungai-sungai yang mengalami kerusakan lingkungan, maka dari itu aparat pemerintah yang melakukan penilaian terhadap izin lingkungan butuh pengawasan yang melekat kalau perlu peran serta masyarakat dilibatkan dalam melakukan pengawasan tersebut salah satu cara adalah dengan membuka dokumen izin lingkungan sebagai dokumen publik yang mudah diakses.

Peran pemerintah lainnya dalam pemenuhan hak atas lingkungan yang baik dan sehat ini adalah ia wajib untuk mengalokasikan anggaran untuk membiayai kegiatan perlindungan dan pengelolaan lingkungan hidup juga pembangunan yang berwawasan lingkungan hidup. Bahkan ketika lingkungan hidupnya telah mengalami pencemara dan/atau perusakan masih merupakan kewajiban pemerintah unduk menetapkan biaya untuk pemulihan lingkungan hidup, sehingga secara tidak langsung ketentuan ini dapat merugikan negara karena pihak pencemar tidak disebutkan sama sekali atau pihak pencemar tidak dilibatkan untuk membiayai. Undang-undang ini juga memiliki ketentuan pidananya yang merupakan suatu tindak kejahatan bukan pelanggaran.

Limbah B3 yang dilepaskan langsung ke lingkungan dapat memberikan dampak negatif yang berbahaya kepada lingkungan juga kesehatan manusia dan makhluk hidup lainnya. Pengelolaan limbah B3 sebenarnya ditujukan untuk limbah yang dihasilkan unit produksi sedikit mungkin bahkan kalau bisa sampai nol. Ada dua limbah PLTU Batubara yang masuk dalam kategori bahaya tingkat 2 yaitu fly ash dan bottom ash. Fly ash dan bottom ash merupakan hasil dari proses pembakaran batubara pada fasilitas pembangkitan listrik tenaga uap, boiler dan/atau tungku industri. Ada tiga kategori untuk limbah ini, kategori 1 yang memberikan dampak langsung dan akut terhadap manusia dan dapat dipastikan akan memberikan dampak negatif kepada lingkungan hidup; kategori 2 yang memiliki efek tunda serta tidak memberikan dapak langsung terhadap manusia dan lingkungan hidup. Untuk mengurangi limbah bahan berbahaya dan beracun Peraturan Pemerintah No. 101 Tahun 2014 tentang Pengelolaan Limbah B3 memberikan instruksi dengan tiga cara yaitu melalui "substitusi bahan, modifikasi proses dan/atau penggunaan teknologi ramah lingkungan." Tetapi jika masih menghasilkan limbah B3 maka diupayakan limbah B3 tersebut memberikan manfaat lainnya. Peraturan ini mewajibkan bagi setiap orang yang 
dalam kegiatannya menghasilkan Limbah B3, yang mengumpulkan Limbah B3, yang mengangkut Limbah B3, yang memanfaatkan Limbah B3, yang mengolah Limbah B3 maupun yang menimbun Limbah B3 dan yang melakukan pembuangan Limbah B3 untuk penanggulangan pencemaran lingkungan hidup dan/atau kerusakan lingkungan hidup juga pemulihan fungsi lingkungan hidup.

Peraturan Menteri Lingkungan Hidup No. 8 Tahun 2009 tentang Baku Mutu Air Limbah Bagi Usaha atau Kegiatan Pembangkit Listrik Tenaga Termal yang merupakan turunan dari Peraturan Pemerintah No. 82 Tahun 2001 tentang Pengelolaan Kualitas Air dan Pengendalian Pencemaran Air tidak memberikan aturan spesifik mengenai air laut yang mana menjadi tempat pembuangan air limbah PLTU Batubara, sehingga mengakibatkan tidak memberikan jaminan untuk perlindungan ekosistem pesisir maupun laut. Saat ini sudah ada sekitar 15 PLTU yang beroperasi di kawasan pesisir. Limbah bahang yang merupakan limbah air dari proses PLTU, kalau dibuang kelaut dapat memberikan dampak kenaikan suhu air laut. Toleransi yang diberikan dalam Keputusan Menteri Lingkungan Hidup No. 51 Tahun 2004 peningkatan suhu akibat buangan limbah tidak melebihi 2 derajat celcius, tetapi lain halnya dengan yang ada pada Peraturan Menteri Lingkungan Hidup No. 8 Tahun 2009 yang mana 20x lipat dari Kepmen sebelumnya yaitu 40 derajat ketika dibuang ke air penerima limbah.

Sebenarnya semua peraturan yang telah disebutkan sebelumnya sudah mengacu pada pembangunan berkelanjutan yang berwawasan lingkungan. Maksud pembangunan berkelanjutan yang berwawasan lingkungan yang disebutkan dalam beberapa peraturan terdahulu dijelaskan lebih lanjut dalam penjelasan pasal Undang-Undang Nomor 32 Tahun 2009 yaitu kriteria kinerja perlindungan dan pengelolaan lingkungan hidup meliputi kinerja mempertahankan kawasan konservasi dan penurunan tingkat pencemaran dan/atau kerusakan lingkungan hidup. Sehingga seluruh pengaturan yang ada dapat dikatakan telah memberikan jaminan terhadap hak atas lingkungan yang baik dan sehat. Tetapi timbul sebuah permasalahan baru yaitu pada implementasinya. Misalnya di PLTU Batubara yang ada di Cilacap, yang letaknya di pinggir pantai. Akibat keberadaan PLTU Batubara ini nelayan harus berlayar lebih jauh lagi untuk mendapatkan ikan, bahkan pendapatan ikan saat ini cukup sulit. Ekosistem laut bisa saja rusak akibat kapal tongkang yang membawa batubara tersebut, karena dalam memindahkan batubara tersebut bakal ada batubara yang jatuh ke laut. Di Jepara pun demikian, PLTU Batubara yang terletak didekat dipemukiman warga yang lokasinya seperti di Cilacap yaitu pada pinggiran pantai, banyak anak-anak yang bermain di pantai tersebut. Padahal asap yang ditimbulkan oleh PLTU Batubara tersebut dapat menimbulkan 
masalah pernapasan. Dalam bernapas seharusnya tidak akan mengancam jiwa manusia.

\section{Konsep Pengaturan Kedepannya}

Untuk konsep pengaturan kedepannya, sebagai pemerintah, pemerintah daerah yang memiliki peran dan tanggung jawab untuk pemenuhan hak atas lingkungan hidup yang baik dan sehat sebaiknya melakukan pembenahan mulai dari norma hukum yang ada :

Dari segi substansi hukumnya, seperti yang telah disebutkan sebelumnya bahwa sebenarnya seluruh pengaturan mengenai PLTU Batubara ini telah memberi kita jaminan terhadap perlindungan dan pemenuhan hak atas lingkungan hidup yang baik dan sehat. Tetapi pada beberapa pengaturan tidak disebutkan lebih spesifik antara jarak PLTU Batubara dengan pemukiman warga diharuskan berapa kilometer, karena izin lokasi dikeluarkan oleh pemerintah daerah setempat. Seperti yang ada pada PERMEN LH No. 4 Tahun 2012 tentang Indikator Ramah Lingkungan Untuk Usaha dan/atau Kegiatan Penambangan Terbuka Batubara yang mengatr jarak antara tepi lubang galian dengan pemukiman warga adalah minimal 500 Meter. Aturan mengenai Clean Air Act sepertinya sudah dibutuhkan oleh Indonesia, selain itu aturan yang ada harus tegas dan khusus menangani bahaya dari PLTU Batubara. Hukum mengenai kualitas udara seharusnya lebih melindungi kita.

Sedangkan untuk budaya hukumnya, saya rasa perlu untuk optimalisasi dan realokasi sumber daya energi baru terbarukan (EBT). Apalagi seperti yang telah disebutkan sebelumnya bahwa dalam Rencana Usaha Penyediaan Tenaga Listrik (RUPTL) porsi PLTU Batubara sebesar 50an persen. Sedangkan untuk EBT hanya sekitar 20an persen saja. Lebih berfokus juga pada pembangunan yang berwawasan lingkungan sebagaimana amanat undang-undang, serta pembangunan yang berkelanjutan. Jangan lagi bergantung pada PLTU Batubara, karena di banyak negara maju eksistensi PLTU Batubara sudah ketinggalan zaman. Saya rasa segala bentuk dokumen berkaitan dengan izin lingkungan, izin lokasi, maupun izin operasi dari PLTU Batubara barangkali bisa dipublikasikan secara transparan agar masyarakat lain dapat menilai berbagai dokumen tersebut.

Dalam penegakan hukum mungkin aparat harus lebih bertindak tegas apabila PLTU Batubara menghasilkan polusi yang melebihi standarnya. Standar ini pula seharusnya diperkuat dengan langkah yang lebih ketat dalam pemantauan polusi udara. Mungkin kita perlu menambah biaya tambahan untuk NOx dan PM 2.5 yang dihasilkan. Juga pertanggungjawaban produsen listrik 
akibat kelebihan emisi dan polusi udara dalam rangka untuk tidak melanggar hukum dan melampaui batas emisi. Selain itu bekas-bekas galian tambang yang harus direklamasi terkadang tidak direklamasi oleh Perusahaan yang bertanggungjawab akan hal tersebut. Padahal ketentuan reklamasi jelas diamanatkan oleh Peraturan Pemerintah No. 78 Tahun 2010 tentang Reklamasi dan Pascatambang, yang mana dalam PP tersebut mewajibkan dilakukannya reklamasi paling lambat 30 (tiga puluh) hari kalender semenjek setelah sebagian atau seluruh kegiatan usaha pertambangan berakhir. Tetapi masih ada saja perusahaan yang tidak melakukan hal tersebut. Pemerintah, Pemerintah Daerah, dan Masyarakat seharusnya lebih aktif dalam melakukan pengawasan, terutama Kementrian Lingkungan Hidup dan Kehutanan terhadap pengawasan dan pemeriksaan menyeluruh dari dampak lingkungan yang berkelanjutan dari PLTU Batubara ini.

Pembangunan berkelanjutan dan berwawasan lingkungan yang disinggung sebelumnya memiliki dua aspek penting, tentu aspek pembangunannya dan aspek lingkungannya. Seperti yang telah disebutkan sebelumnya bahwa UndangUndang Nomor 32 Tahun 2009 telah memberikan konsep terhadap pembangunan berkelanjutan dan berwawasan lingkungan ini. Tujuannya adalah sebagai bentuk jaminan terhadap generasi yang akan datang pada aspek lingkungan hidup serta keselamatan, kemampuan, kesejahteraan dan mutu hidup nantinya. Ada 6 sasaran yang pembangunan berkelanjutan menurut Sutamihardja16: "pertama, penekanan terhadap sumber daya alam yang unreplaceable dan pemanfaatan yang mengarahkan pada sumber daya alam yang replaceable; kedua, safeguarding atau melakukan pencegahan terhadap gangguan ekosistem agar kelestarian sumber daya alam dan lingkungan tetap terjaga kualitasnya; ketiga, sumberdaya alam yang dikelola dan dimanfaatkan hanya untuk pertumbuhan ekonomi; keempat, kesejahteraan masyarakat yang berkelanjutan harus dipertahankan; kelima, dalam melakukan pembangunan ataupun pengelolaan sumber daya alam harus memberikan manfaat jangka panjang; keenam, mutu dan kualitas kehidupan manusia harus dijaga." Emil salim memberikan pendapat bahwa ada lima pokok yang dapat dilakukan untuk melaksanakan pembangunan berwawasan lingkungan yaitu17 : "pertama, menumbuhkan sikap kerja berdasarkan kesadaran saling membutuhkan antara satu dengan yang lain; kedua, kemampuan menyerasikan kebutuhan dengan kemampuan sumber alam dalam menghasilkan barang dan jasa; ketiga, mengembangkan sumber daya manusia agar mampu

\footnotetext{
16 Sutamihardja, dalam Mira Rosana, "Kebijakan Pembangunan Berkelanjutan Yang Berwawasan Lingkungan Di Indonesia”, Jurnal KELOLA: Jurnal Ilmu Sosial Vol. 1 No. 1 (2018), hlm. 155-156

${ }^{17}$ Ibid., hlm. 160
} 
menanggapi tantangan pembangunan tanpa merusak lingkungan; keempat, mengembangkan kesadaran lingkungan di kalangan masyarakat sehingga tumbuh menjadi kesadaran berbuat; kelima, menumbuhkan lembaga-lembaga swadaya masyarakat yang dapat mendayagunakan dirinya untuk menggalakkan partisipasi masyarakat dalam mencapai tujuan pengelolaan lingkungan hidup."

\section{Penutup}

Berikut beberapa kesimpulan yang dapat ditarik sebagai berikut. Pertama, Pasal 3 huruf g Undang-Undang Nomor 32 Tahun 2009 tentang Perlindungan dan Pengelolaan Lingkungan Hidup yang memberikan jaminan untuk pemenuhan dan perlindungan lingkungan hidup sebagai bagian dari hak asasi manusia. Kalau dilihat semua pengaturan yang menjadi landasan mengenai PLTU Batubara telah memberikan perlindungan dan pemenuhan terhadap hak atas lingkungan hidup yang baik dan sehat. Kedua, konsep pengaturan kedepannya dilihat dari tiga aspek yaitu substansi hukum, budaya hukum, serta penegakkan hukum. Dari aspek substansi hukumnya dapat dilihat juga tidak ada pengaturan yang jelas dan tegas mengenai PLTU Batubara. Untuk budaya hukumnya, lebih difokuskan pada pembangunan yang berkelanjutan dan berwawasan lingkungan. Serta penegakkan hukumnya, masih ada beberapa aturan yang tidak dijalankan oleh perusahaan yang bersangkutan misalnya dalam penambangan batubara.

Saran yang dapat diberikan sebagai berikut. Pertama, melakukan pengawasan, memperkuat aturan, serta menindak tegas bagi pelanggar aturan dari PLTU Batubara ini, baik itu dari hulu ke hilir (maksudnya dari pertambangan batubara hingga ke pembakaran di PLTU). Kedua, memfokuskan pada pembangunan yang berkelanjutan yang berwawasan lingkungan sebagaimana amanat undang-undang. Juga mendukung pengembangan teknologi energi terbarukan, dan berfokus pada energi terbarukan yang ada di Indonesia. Ketiga, peran pemerintah terhadap perubahan iklim harus lebih baik. PLTU batubara merupakan penyumbang terbesar karbon dioksida $\left(\mathrm{CO}_{2}\right)$, padahal pemerintahan memiliki komitmen untuk mengurangi emisi gas rumah kaca. Sehingga perlu memperhatikan kembali terkait kebijakan pembangkit listrik tenaga batubara yang mana eksistensinya telah menurun bagi dunia.

\section{Daftar Pustaka}

\section{Buku}

Ahmad Zein, Yahya, Hak Warga Negara Di Wilayah Perbatasan (Perlindungan Hukum Hak Atas Pendidikan dan Kesehatan), Liberty, Yogyakarta, 2016. 
Muchtar, Masrudi, et.al., Hukum Kesehatan Lingkungan (Kajian Teoritis dan Perkembangan Pemikiran), Pustaka Baru Press, Yogyakarta, 2017.

Slamet Kurnia, Titon, Derajat Kesehatan Optimal sebagai HAM di Indonesia, PT Alumni, Bandung, 2007.

\section{Jurnal}

I Made Astra, "Energi dan Dampaknya Terhadap Lingkungan", Jurnal Meteorologi dan Geofisika, Vol. 11 No. 2, November 2010.

Rika Erawaty dan Siti Kotijah, "Hak Masyarakat Atas Lingkungan Hidup yang Baik dan Sehat" Risalah Hukum, Vol. 9 No. 1 Juni 2013.

Sutamihardja, dalam Mira Rosana, "Kebijakan Pembangunan Berkelanjutan Yang Berwawasan Lingkungan Di Indonesia", Jurnal KELOLA: Jurnal Ilmu Sosial Vol. 1 No. 1 (2018),

\section{Lapoaran}

Greenpeace, "Internalisasi Dampak dan Biaya Kesehatan dari Pembangkit Listrik Tenaga Uap (PLTU) Batubara di Indonesia", Laporan, September 2016

\section{Perundang-undangan}

Undang-Undang Dasar Negara Republik Indonesia Tahun 1945

Undang-Undang Nomor 32 Tahun 2009 tentang Perlindungan dan Pengelolaan Lingkungan Hidup

\section{Internet}

https:/ /id.wikipedia.org/wiki/Daftar_pembangkit_listrik_di_Indonesia “Daftar Pembangkit Listrik di Indonesia" Akses tanggal 12 Agustus 2019

https:/ / news.detik.com/dw/d-4001541/who-7-juta-orang-tewas-tiap-tahunkarena-polusi-udara "WHO: 7 Juta Orang Tewas Tiap Tahun Karena Polusi Udara" Akses 8 Agustus 2019

https: / / www.beritamoneter.com/pltu-mendominasi-5697-program-listik-35-000mw / akses tanggal 25 Februari 2020

Khoirullah Thofu "PLTU: ENERGI KOTOR YANG DIHASILKAN PRODUKSI LISTRIK BATUBARA (HULU DAN HILIR)" dalam https:/ / www.lbhbali.or.id/berita/read/121/PLTU:-ENERGI-KOTORYANG-DIHASILKAN-PRODUKSI-LISTRIK-BATUBARA--HULU-DANHILIR-.html akses tanggal 25 Februari 2020 